\title{
Susceptibility of White-Tailed Deer to Rift Valley Fever Virus
}

\author{
William C. Wilson, In Joong Kim, \\ Jessie D. Trujillo, Sun Young Sunwoo, \\ Leela E. Noronha, Kinga Urbaniak, \\ D. Scott McVey, Barbara S. Drolet, Igor Morozov, \\ Bonto Faburay, Erin E. Schirtzinger, \\ Tammy Koopman, Sabarish V. Indran, \\ Velmurugan Balaraman, Juergen A. Richt
}

Rift Valley fever virus, a zoonotic arbovirus, poses major health threats to livestock and humans if introduced into the United States. White-tailed deer, which are abundant throughout the country, might be sentinel animals for arboviruses. We determined the susceptibility of these deer to this virus and provide evidence for a potentially major epidemiologic role.

$\mathrm{R}_{\mathrm{p}}^{\mathrm{i}}$ ift Valley fever virus (RVFV) is a zoonotic, arthropodborne RNA virus (order Bunyavirales, family Phenuiviridae, genus Phlebovirus) $(1,2)$. The virus is maintained in nature in a mosquito-vertebrate host cycle and is endemic to sub-Saharan Africa where epidemics have great consequences for livestock and human health. There is potential for RVFV incursions into neighboring regions or introductions into other continents, including North America, which has mosquito species capable of harboring and transmitting RVFV (3).

Although domestic cattle, sheep, and goats are susceptible to RVFV and function as amplification hosts during epidemics, the potential role of wildlife host species, such as white-tailed deer (Odocoileus virginianus) is unknown. RVFV is capable of infecting a range of cell lines from wildlife in North America, including white-tailed deer (4), suggesting in vivo susceptibility. White-tailed deer might be good sentinel animals for various arboviruses because of their abundance and wide geographic distribution in the United States (5).

A serious concern is that white-tailed deer could serve as reservoir or amplification hosts for RVFV (6-9).

Author affiliations: US Department of Agriculture, Manhattan,

Kansas, USA (W.C. Wilson, L.E. Noronha, D.S. McVey,

B.S. Drolet, E.E. Schirtzinger); Kansas State University College

of Veterinary Medicine, Manhattan (I.J. Kim, J.D. Trujillo,

S.Y. Sunwoo, K. Urbaniak, I. Morozov, B. Faburay, T. Koopman,

S.V. Indran, V. Balaraman, J.A. Richt)

DOI: https://doi.org/10.3201/eid2409.180265
Furthermore, modeling suggests that these deer as reservoir hosts would enhance spillover of RVFV into human populations because of overlap of mosquitoes, humans, and wildlife in urban and periurban areas (7). Therefore, we determined the susceptibility of white-tailed deer to RVFV infection and described the potential role of whitetailed deer populations in RVFV epidemiology.

\section{The Study}

Wild-type RVFV (Kenya 2006 strain 128B-15, KEN06) was propagated in $\mathrm{C} 6 / 36$ mosquito cells and prepared as inoculum $\left(1 \times 10^{6} \mathrm{PFU} /\right.$ animal $)$. Five 5-month-old male white-tailed deer from the US Department of Agriculture, Agricultural Research Service, National Animal Disease Center (Ames, IA, USA) captive herd were acclimated to Biosafety Level 3 conditions and housed in such a facility with specifically designed paneling.

After sedation and blood collection ( 0 days postinoculation [dpi]), 4 animals were injected subcutaneously in the neck with virus inoculum; 1 contact control animal was sham inoculated with cell culture medium. To minimize stress, 2 animals in the virus-inoculated group were sedated on alternating days (2-6 dpi) and then at 10 and 14 dpi for blood collection and physical examination. The control was sedated and sampled at 2, 4, 6, and 7 dpi. Animals were initially monitored 2 times/day, then 3 times/day after development of fever.

We determined blood levels of albumin, alkaline phosphatase, $\gamma$-glutamyl transferase, aspartate aminotransferase, and blood urea nitrogen by using a VetScan VS2 Analyzer (Abaxis, Union City, CA, USA). We used a quantitative reverse transcription PCR (qRT-PCR) to detect RVFV RNA (10). We performed humane euthanasia and necropsy when deer were moribund or at the end of the study (14 dpi). All animal work was performed at the Biosecurity Research Institute, Kansas State University (Manhattan, KS, USA), in compliance with Institutional Animal Care and Use Committee protocol no. 3518 .

The 5 deer adapted well to the specifically designed room. Rectal temperatures were in the standard range $\left(37.5^{\circ} \mathrm{C}-40.1^{\circ} \mathrm{C}\right)(11)$ at $0 \mathrm{dpi}$ (Table). On dpi 2, clinical assessment of 2 infected deer (nos. 43 and 44) and the control (no. 41) showed that 1 inoculated animal (no. $44 ; 41.3^{\circ} \mathrm{C}$ ) and the control $\left(41.2^{\circ} \mathrm{C}\right)$ had increased body temperatures. Also, the control was highly agitated during capture. 
Table. Assessment of Rift Valley fever virus infection in 5 white-tailed deer at selected days postinfection*

\begin{tabular}{|c|c|c|c|c|c|c|c|c|}
\hline \multirow{3}{*}{$\begin{array}{l}\text { Group, } \\
\text { animal no. } \\
\text { Mock }\end{array}$} & \multicolumn{8}{|c|}{ Day postinoculation, real-time qRT-PCR/virus isolation results, temperature, ${ }^{\circ} \mathrm{C}$} \\
\hline & 0 & 2 & 3 & 4 & 6 & 7 & 10 & 14 \\
\hline & & & & & & & & \\
\hline 41 & $-I-, 39.2$ & $-I-, 41.0$ & NC & $+/+, 39.6$ & $+++/+++, 40.7$ & $\begin{array}{c}+++/+++, 41.2 \\
\text { euthanized }\end{array}$ & NA & NA \\
\hline Ken 06 & & & & & & & & \\
\hline 43 & $-1-, 39.3$ & $++/++, 40.2$ & $\mathrm{NC}$ & $+/+, 39.0$ & $-1-, 40.6$ & $\mathrm{NC}$ & $-/-, 39.1$ & $-1-, 39.0$ \\
\hline 44 & $-1-, 39.4$ & $+++/+++, 41.3$ & $+++/+++$, died & NA & NA & NA & NA & NA \\
\hline 47 & $-1-, 39.5$ & $\mathrm{NC}$ & $+++/+++$, died & NA & NA & NA & NA & NA \\
\hline 52 & $-1-, 39.2$ & $\mathrm{NC}$ & $\mathrm{NC}$ & $+/+, 39.3$ & $-1-, 39.9$ & $\mathrm{NC}$ & $-/-, 39.5$ & $-1-, 39.1$ \\
\hline
\end{tabular}

*Bold indicates increased body temperature. NA, not available; NC, not collected; qRT-PCR, quantitative reverse transcription PCR; - , negative; +, cycle threshold range 31-35, $1 \times 10^{1}-1 \times 10^{3} \mathrm{PFU} / \mathrm{mL} ;++$, cycle threshold range $25-30,1 \times 10^{4}-1 \times 10^{6} \mathrm{PFU} / \mathrm{mL} ;+++$, cycle threshold $<25,1 \times 10^{7}-1 \times 10^{8}$ $\mathrm{PFU} / \mathrm{mL}$.

qRT-PCR analysis of RNA isolated from serum samples obtained 2 dpi showed high concentrations of circulating virus RNA in deer no. $44\left(8.15 \times 10^{10}\right.$ copies $\left./ \mathrm{mL}\right)$ and high concentrations in deer no. $43\left(3.0 \times 10^{7}\right.$ copies/ $\mathrm{mL}$ ). We did not detect RVFV RNA in serum from the control at 2 dpi. Later that day, 2 deer (nos. 44 and 47) were less active, and diffuse bilateral hyperemia of the ocular sclera developed in deer no. 44. At 3 dpi, bloody diarrhea developed in these 2 deer, and they died suddenly. qRT-PCR showed high serum levels of RVFV RNA (1 $\times 10^{11}$ copies $/ \mathrm{mL}$ in deer no. 44 and $1 \times 10^{12}$ copies $/ \mathrm{mL}$ in deer no. 47).

Necropsy findings were similar for both animals and included severe, multifocal, hemorrhagic hepatic necrosis; moderate to severe segmental to diffuse hemorrhagic enteritis; moderate pulmonary edema; and moderate to severe hemorrhagic lymphadenopathy (Figure). Hepatic necrosis and petechiae have also been found in cattle and sheep with acute RVFV infections $(12,13)$. Enteric lesions

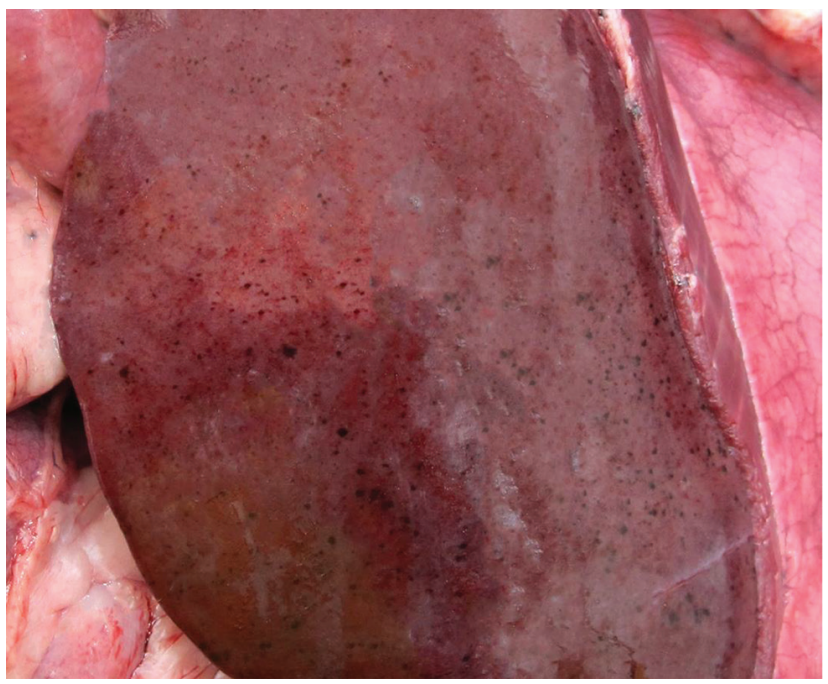

Figure. Gross pathologic view of liver of white-tailed deer no. 44 after experimental infection with Rift Valley fever virus inoculum. The animal died at day 3 postinoculation; at necropsy, the liver showed severe, multifocal, hemorrhagic hepatic necrosis attributed to acute infection with Rift Valley fever virus. appeared to be severe and unique to white-tailed deer. Bloody fecal material covered the perineum, ventral tail, and hind limbs. Segmental hemorrhage of gastrointestinal mucosa was most severe in deer no. 44 . We found watery and bloody gastrointestinal contents from the abomasum to the rectum (deer no. 44) or small intestine to the rectum (deer no. 47). Mesenteric and gastrohepatic lymph nodes of both animals were edematous and had multifocal hemorrhagic foci. We observed diffuse thymic hemorrhage in deer no. 44.

The remaining animals were bright, alert, and responsive at 3 dpi. However, 2 deer (nos. 43 and 52) had transient diarrhea with loose feces persisting until 6 dpi. qRT-PCR of serum showed moderate levels of RVFV RNA in deer no. 43 and deer no. 52. We also detected a low concentration $\left(1 \times 10^{3}\right.$ copies $\left./ \mathrm{mL}\right)$ of RVFV RNA in the control by $4 \mathrm{dpi}$, indicative of horizontal transmission. On day 6 , the control and 1 inoculated deer (no. 43) had slightly increased body temperatures $\left(40.7^{\circ} \mathrm{C}\right.$ for the control and $40.6^{\circ}$ for no. 43$)$. By day 6 , serum RVFV RNA concentration for the control had increased to $\approx 1 \times 10^{10}$ copies $/ \mathrm{mL}$, and concentrations of virus RNA in deer no. 47 and no. 52 had decreased to $1 \times 10^{2}-1 \times 10^{3}$ copies $/ \mathrm{mL}$. By $7 \mathrm{dpi}$, the control was recumbent and febrile $\left(41.2^{\circ} \mathrm{C}\right)$ and marked swelling of the left hind limb had developed, which warranted euthanasia.

At necropsy for the control, hepatic and gastrointestinal lesions attributed to RVFV infection were similar to those in deer no. 44 and no. 47 , albeit much less severe. Examination of the markedly swollen left hind limb showed marked expansion of subcutis and fascia with hemorrhage and emphysema but definite diagnosis is pending further investigation. RVFV infection of the control was supported by the high serum level of RVFV RNA at 7 dpi $\left(8.1 \times 10^{8}\right.$ copies $\left./ \mathrm{mL}\right)$. Serum qRT-PCR showed RVFV RNA in deer no. $43\left(1 \times 10^{3}\right.$ copies $\left./ \mathrm{mL}\right)$ but not in deer no. 52 at 10 dpi. By 14 dpi (end of the study), we did not detect RVFV RNA in serum of either remaining animal. We did not observe gross lesions in the remaining deer (nos. 43 and 52) at the end of the study. However, we detected RVFV RNA in liver, kidneys, spleen, and lymph nodes from both animals. 


\section{Conclusions}

Clinical signs, gross pathology, and qRT-PCR-determined virus RNA loads demonstrated that white-tailed deer are highly susceptible to RVFV infection, causing hepatic necrosis and hemorrhage. Supporting this conclusion, we found that levels of aspartate aminotransferase increased in serum of all animals when blood was collected at the time of clinical illness (range 91-153 $\mathrm{U} / \mathrm{L}$ at 0 dpi and $629-3,543 \mathrm{U} / \mathrm{L}$ at the time of clinical illness). Similar results were reported for previous experimental RVFV infections of domestic cattle and sheep $(12,13)$.

In addition, and unique to this study, RVFV infection in white-tailed deer resulted in development of hemorrhagic enteritis and bloody diarrhea at the time of peak viremia in 2 infected deer (nos. 44 and 47), which likely enabled horizontal transmission of RVFV to the control animal. Additional laboratory analysis is ongoing. However, our results clearly indicate that white-tailed deer in North America are susceptible to RVFV infection. Infected white-tailed deer died from the infection $(n=2)$, might survive the infection $(n=2)$, and can transmit the virus through direct contact $(n=1)$, presumptively by the fecal-oral route.

This study indicates that white-tailed deer in North America are highly susceptible to RVFV and capable of horizontal virus transmission. The potential role of other wildlife in the epidemiology of RVFV should be evaluated.

\section{Acknowledgments}

We thank Rebecca Cox for providing assistance with whitetailed deer acclimatization before the study and Mallory Hoover, the Biosecurity Research Institute, and staff of the Kansas State University Comparative Medicine Group for providing assistance.

This study was supported by the Department of Homeland Security Center of Excellence for Emerging and Zoonotic Animal Diseases (grant no. 2010-ST061-AG0001), the Kansas National Bio and Agro-Defense Facility Transition Fund, the Kansas Bioscience Authority, and the US Department of Agriculture (project no. 59-32000-009-00D).

\section{About the Author}

Dr. Wilson is a research microbiologist at the US Department of Agriculture, Manhattan, KS. His research interests are understanding virus-vector-host interactions and developing means to detect and control arboviruses.

\section{References}

1. International Committee on Taxonomy of Viruses. ICTV 10th report, 2011 [cited 2017 Aug 6]. https://talk.ictvonline.org/ ictv-reports/ictv_9th_report/

2. Rima B, Collins P, Easton A, Fouchier R, Kurath G, Lamb RA, et al.; ICTV Report Consortium. ICTV virus taxonomy profile: Pneumoviridae. J Gen Virol. 2017;98:2912-3. http://dx.doi.org/ 10.1099/jgv.0.000959

3. Turell MJ, Wilson WC, Bennett KE. Potential for North American mosquitoes (Diptera: Culicidae) to transmit rift valley fever virus. J Med Entomol. 2010;47:884-9. http://dx.doi.org/10.1093/ jmedent $/ 47.5 .884$

4. Gaudreault NN, Indran SV, Bryant PK, Richt JA, Wilson WC. Comparison of Rift Valley fever virus replication in North American livestock and wildlife cell lines. Front Microbiol. 2015;6:664. http://dx.doi.org/10.3389/fmicb.2015.00664

5. Pedersen K, Wang E, Weaver SC, Wolf PC, Randall AR, Van Why KR, et al. Serologic evidence of various arboviruses detected in white-tailed deer (Odocoileus virginianus) in the United States. Am J Trop Med Hyg. 2017;97:319-23. http://dx.doi.org/10.4269/ajtmh.17-0180

6. Hartley DM, Rinderknecht JL, Nipp TL, Clarke NP, Snowder GD, Nipp TL, et al.; National Center for Foreign Animal and Zoonotic Disease Defense Advisory Group on Rift Valley Fever. Potential effects of Rift Valley fever in the United States. Emerg Infect Dis. 2011;17:e1.

7. Kakani S, LaBeaud AD, King CH. Planning for Rift Valley fever virus: use of geographical information systems to estimate the human health threat of white-tailed deer (Odocoileus virginianus)related transmission. Geospat Health. 2010;5:33-43. http://dx.doi.org/10.4081/gh.2010.185

8. Kasari TR, Carr DA, Lynn TV, Weaver JT, Lynn TV, Lynn TV, et al. Evaluation of pathways for release of Rift Valley fever virus into domestic ruminant livestock, ruminant wildlife, and human populations in the continental United States. J Am Vet Med Assoc. 2008;232:514-29. http://dx.doi.org/10.2460/javma.232.4.514

9. Golnar AJ, Kading RC, Hamer GL. Quantifying the potential pathways and locations of Rift Valley fever virus entry into the United States. Transbound Emerg Dis. 2017;179:1397.

10. Wilson WC, Romito M, Jasperson DC, Weingartl H, Binepal YS, Maluleke MR, et al. Development of a Rift Valley fever real-time RT-PCR assay that can detect all three genome segments. J Virol Methods. 2013;193:426-31. http://dx.doi.org/10.1016/ j.jviromet.2013.07.006

11. Rogers LL, Moen AN, Shedd ML. Rectal temperatures of 2 free-ranging white-tailed deer fawns. Journal of Wildlife Management. 1987;51:59-62. http://dx.doi.org/10.2307/3801631

12. Faburay B, Gaudreault NN, Liu Q, Davis AS, Shivanna V, Sunwoo SY, et al. Development of a sheep challenge model for Rift Valley fever. Virology. 2016;489:128-40. http://dx.doi.org/ 10.1016/j.virol.2015.12.003

13. Wilson WC, Davis AS, Gaudreault NN, Faburay B, Trujillo JD, Shivanna V, et al. Experimental infection of calves by two genetically-distinct strains of Rift Valley fever virus. Viruses. 2016;8:145. http://dx.doi.org/10.3390/v8050145

Address for correspondence: William C. Wilson, US Department of Agriculture, Agricultural Research Service, Center for Grain and Animal Health Research, Arthropod-Borne Animal Diseases Research Unit, 1515 College Ave, Manhattan, KS 66502, USA; william.wilson@ars.usda.gov 